\title{
Chapter 1 \\ Potted Review of Economic Theory: The Complex Evolving System
}

\author{
Benjamin Aaron Rosen
}

\subsection{A Potted Review}

Humans live in material intercourse with both nature and each other to sustain life. These arrangements, which broadly fall under the notion of 'economics', have not always bankrupted nature. The long hunter-gatherer phase of human existence, in general, left a small ecological footprint. Nevertheless, many civilizations and even smaller-scale societies have destroyed their ecosystems through loss of topsoil, extinction of over-exploited species or failure of overly elaborate and inflexible arrangements; for example, dependence on complex irrigation systems that fail when drought strikes. ${ }^{1}$ The rise of fossil-fuel based economies, originating in the West in the 19th century and expanded globally by the late 20th, has produced a rise in living standards and population that is unprecedented, but that rise is now hitting ecological limits. How have Western ideas of economics dovetailed with this economic dynamism and ecological destruction? What can be gained by going back to models that, in terms of their human balance in nature, and perhaps their balanced relations among people as well, were more successful? In this chapter, and in this analysis as a whole, we will address these questions.

The original version of this chapter was revised. The Erratum to this chapter is available at 10.1007/978-3-319-26940-5_5

${ }^{1}$ Diamond, J. (2011) Collapse: How Societies Choose to Fail or Succeed. Penguin Books; Revised edition.

B.A. Rosen ( $\square)$

University of Haifa, Haifa, Israel

(C) The Author(s) 2016 
When Adam Smith, ${ }^{2}$ James Mill, ${ }^{3}$ David Ricardo ${ }^{4}$ and other intellectuals of the 18th and 19th centuries first described the foundations of the free market system, they gave us an account of how the economic machinery that had come into being as a consequence of the Enlightenment and the emerging democratic forms of government constituted around notions of human rights to life, liberty, property and equality, represented the liberation of mankind from the tyranny of kings and priests. In a free market, each individual makes choices by allocating their own resources as they see fit, voting in the perpetual democracy of the market that, in turn, controls the allocation of natural and human resources to best supply demand. The self-interest of individuals is harnessed by market mechanisms to serve the common good. In Adam Smith's words:

It is not from the benevolence of the butcher, the brewer, or the baker that we expect our dinner, but from their regard to their own self-interest. We address ourselves not to their humanity but to their self-love, and never talk to them of our own necessities, but of their advantages.

Demand is a word used by economists, but it is not a dry monetary term. It is the expression of desire, the condensation of the needs and wants of many individuals. It is a psychological variable. Demand is one half of the collective process that automatically adjusts economic activity throughout the economy. Supply, the collective willingness to provide, is likewise a description of the psychological states of mind of the complementary agents in acts of trade. In a free market, the meeting of supply and demand at agreed-upon prices can be thought of as an expression of liberty and the right to own and trade one's property. The automatic mechanism of the market is an invisible hand, an idiom borrowed from Adam Smith, that directs human affairs to desirable ends.

The Italian economist, Vilfredo Pareto, ${ }^{5}$ argued with the help of mathematical models borrowed from engineering that an unencumbered free market leads to the best possible allocation of resources for human needs; that at its optimum, any change of price will lead to lower net wealth creation and less efficient allocation of resources. Changes by means of taxation, price fixing or subsidies cause adjustments throughout the system. There will be losers and winners, but the sum of the losses will be greater than the sum of the gains, as the market is driven away from the clearing prices that would be agreed upon within an unencumbered free market. Today, this is known as a Pareto efficient market. ${ }^{6}$

\footnotetext{
${ }^{2}$ Smith, A. (1776) An Inquiry into the Nature and Causes of the Wealth of Nations. Strahan and Cadell, London.

${ }^{3}$ Mill, J. (1813) Money and Exchange. Edinburgh Review.

${ }^{4}$ Ricardo, D. (1817) On the Principles of Political Economy and Taxation. John Murray, London. ${ }^{5}$ Pareto, V. (1909) Cours d'Économie Politique: Nouvelle édition par G.-H. Bousquet et G. Busino, Librairie Droz, Geneva, 1964, pages 299-345.

${ }^{6}$ Mas-Colell, A., Whinston, M.D., Green, J.R. (1995), "Chapter 16: Equilibrium and its Basic Welfare Properties”, Microeconomic Theory. Oxford University Press, ISBN 0-19-510268-1.
} 
These early promises of liberation and optimisation have not stood the test of time. There are many reasons why free markets do not achieve the optimum results that had once been hoped for. For example, the Pareto efficient economy does not necessarily lead to the most just distribution of goods. Remember, the market is a kind of economic democracy in which we vote by means of the allocation of our resources. This is not an egalitarian democracy; rich individuals have a greater impact on the market equilibria than do poor individuals. If buyers or sellers are monopolies, or co-operating oligopolies, the pricing mechanism does not work equitably. Furthermore, the necessities of life may force us to allocate resources in ways we would rather not. We cannot, for example, stop eating because we find the cost of food too high. The opportunities to exploit workers abound, a problem that is not restricted to the Dickensian era of the British industrial revolution, as the exploitation of workers today by companies like McDonald's and Walmart attest.

Jeremy Bentham's moral imperative, the greatest happiness for the greatest number, implies that great suffering by a minority may be justified if it contributes to greater happiness for a majority. This could be interpreted as a justification for the persecution of minorities. Similarly, Pareto efficient markets are insensitive to the needs of the poor. Indeed, a Pareto efficient market could exist in which the majority remains poor while a minority becomes fabulously wealthy. The pursuit of maximum GDP is not the same as the pursuit of social justice.

Achieving Pareto efficiency, irrespective of whether this leads to a just allocation of resources, presumes that all costs and benefits of economic activity enter into the pricing mechanism. However, this is not so. Costs and benefits that do not enter into the pricing mechanism are referred to as externalities. ${ }^{7}$ External costs are often imposed upon the commons or are paid for by individuals who gain no benefit from the goods and services that are produced. When a forest is cut down to make wood for building houses, the people who purchase the houses pay for the costs incurred throughout the production chain. These include the cost of paying for the lumberjacks who cut down the trees, the transport of logs to saw mills, the milling and curing of the wood, the transport of wood to wholesale and retail outlets, the building labour to create the houses, and so on. Other costs, such as cost of energy, enter into the price of the houses by entering into the pricing mechanism at each step at which energy is consumed. However, when the denuded hillsides where forests once stood are no longer available for pleasure, hunting or as habitat for some species, losses are incurred that have not been paid for in the price of the houses. Imagine that the hills become eroded and unstable, as a result of which landslides triggered by heavy rains bury a village in the valley below, and villagers lose their lives and homes. These damages are also prices paid that do not enter into the price of the houses that have been built of the wood harvested from those forests. Likewise, the carbon that was discharged into the atmosphere to supply energy for the production process contributes to climate change and the concomitant costs that this will impose on future generations. These, too, do not enter

\footnotetext{
${ }^{7}$ Pigou, A.C. (1920) The Economics of Welfare. Macmillan and Company, London.
} 
into the price of the houses. Since all economic activity in free markets entails externalities, we can no longer speak of Pareto efficiency as being a meaningful guide for optimum allocation of resources. Instead, we must acknowledge that we have created a system that excels in the pillaging of natural resources, the destruction of nature and the exploitation of certain members of our society. The invisible hand is blind, but unlike Justice, it is often arbitrary in whom it punishes and whom it rewards.

There are other ways in which free markets fail. An ideal market is populated by many independent sellers and buyers, each with perfect knowledge of the market, and all acting as rational agents seeking their own best advantage. However, this is not so in the real world. Few people have perfect knowledge of the markets, and therefore usually make less than optimum choices. Some people make irrational choices because of psychological failings, such as addictions and unwholesome habits. In a world that feeds appetites with temptatious advertising, even the most rational among us occasionally make unwise choices and impulse decisions that we later regret. We are too easily misled into habits of self-centred consumerism. Unfortunately, wisdom is not given to all.

Finally, markets fail when the buyers and sellers are no longer concerned with the utility of the commodities they are trading. By utility, economists mean the usefulness of the commodities for their intended purpose. When we purchase a house to live in, we are motivated by the utility of the house. In contrast, when a speculator purchases a house in anticipation of a future rise in market value, the utility of the house plays a secondary role in the decision to trade. Speculative trade leads to market instability. Bubbles form as speculators chase expectations of capital gains, and busts follow when there is a rush to sell in a falling market. This is an intractable problem, for there is no way to detect which trades are utilitarian and which are speculative. It is not possible to legislate against or control speculative trade. A free market, by definition, must be free for all.

\subsubsection{Where Has This Taken Us?}

Today, we are destroying the natural environment on an unprecedented scale and at a rate exceeding any prior biologically-induced change. In 1989, the world passed a fossil fuel turning point; the quantity of new discoveries of gas, oil and coal deposits became for the first time less than the quantity of these resources consumed. Except for some blips associated with Arctic finds and fracking shale, and a temporary levelling of the curve because of the recent recession, the world's reserves are running down. Our exploitation of fossil fuels has always been unsustainable, but now the end is in sight. ${ }^{8}$

\footnotetext{
${ }^{8}$ IEA (2006) World Energy Outlook 2006. Paris and Washington, D.C. Organisation for Economic
} Co-operation and Development, International Energy Agency. 
Contemporary industrial agriculture is unsustainable. ${ }^{9}$ It is energy-driven at every phase. Energy is consumed to plough the land, and to apply artificial fertilizer, which is itself largely a petroleum product. More energy is used for seeding. And even more energy is used to apply herbicide, insecticide, and fungicide, and to pump and spray water in irrigated areas. And yet more energy is used to harvest, in processing, packaging and transporting food to market. In many places, agriculture is draining aquifers and salinating the soil. Intense agriculture also destroys soil quality by killing the natural soil ecology, so that each year greater levels of artificial inputs are required to coax a crop from the increasingly dead land. Runoff is despoiling the rivers and oceans with pollutants, and triggering toxic algal blooms at sea. Use of toxic sprays bleeds out into the environment, damaging the natural ecology. Desertification has always followed in the footsteps of mankind, but never more so than today. In summary: Industrial agriculture is consuming large amounts of fossil fuel, putting carbon in the atmosphere, destroying soil quality and draining aquifers, damaging natural ecosystems and despoiling rivers and oceans. A recent UN report ${ }^{10}$ concluded $^{-}$ that the industrial agricultural sector would be bankrupt today if the full cost of food production were internalized. We are only able to continue with industrial agriculture because a large part of the cost is placed in the commons. Ultimately, these costs are being paid elsewhere, or will have to be paid by future generations.

In the argument above, we briefly addressed the building of wooden houses and industrial agriculture. We must not forget that almost every form of economic activity imposes costs on the commons. Our children and grandchildren will be made to pay some of the costs of our food, housing, education, entertainment, transport and medical care. Indeed, every aspect of our economic lives leaves a trail of debt behind us. In some cases the debt is paid immediately by people in other countries; for example, the export of obsolescent consumer electronic devices to Africa and the Indian subcontinent imposes a burden of pollution in heavy metals and other toxins on far-away people most of us will never see.

What can be done about this? Can we expect morally responsible behaviour to occur spontaneously in any society? Adam Smith noted ${ }^{11}$ :

I have never known much good done by those who affected to trade for the public good.

In 1968, Garrett Hardin described The Tragedy of the Commons ${ }^{12}$ in a paper on population. Using an example originally devised by William Foster Lloyd, ${ }^{13}$ he

\footnotetext{
${ }^{9}$ Hilton, S. (2015) More Human: Designing a World Where People Come First. W.H. Allan, London.

${ }^{10}$ Hoffmann, U. et al., (2013) Wake Up Before it is too Late: Make Agriculture Truly Sustainable Now for Food Security in a Changing Climate. Trade and Environment Review. United Nations Conference on Trade and Development.

${ }^{11}$ Smith, A. (1776) An Inquiry into the Nature and Causes of the Wealth of Nations. Strahan and Cadell, London.

${ }^{12}$ Hardin, G. (1968) The Tragedy of the Commons. Science, volume 162, pages 1243-48.

${ }^{13}$ Lloyd, W.F. (1833) Two Lectures on the Checks to Population. Oxford University Press, Oxford.
} 
described how a group of farmers competing for use of a shared public resource will over-exploit and under-invest in the commons. Lloyd's model illustrates how it is in the best self-interest of each farmer to extract as much from the commons as possible, even to the point of over-grazing, for by extraction, the individual gains $100 \%$ of the benefit but only a fraction of the losses that are shared by all farmers using the commons. Similarly, it is not in the interest of any one farmer to make a contribution to the commons, since he will pay $100 \%$ of the cost but gain only a fraction of the benefit, while all others sharing the commons will become freeloaders on his contribution. It is therefore in the rational best self-interest of every individual to pillage the resources of the commons without investing in the preservation or development of same.

The Tragedy of the Commons includes the discharge of pollution: chemicals and heat into rivers, toxic waste into the air and oceans, rubbish on the streets and in parks, noise and stink around industrial installations and airports. The polluter gains $100 \%$ of the benefit of being rid of his waste, but suffers only a fraction of the burden. It is therefore in the rational best self-interest of each individual to dispose of his waste into the commons without regard for the price paid by others. And likewise, there is no rational self interest in being the one to do the cleaning up.

The Tragedy of the Commons explains why we inevitably pillage the resources of the earth and foul our planet with waste, each of us in pursuit of our individual self-interest. What is in the best individual self-interest when practiced by many is not in the collective interest to such a degree that individual interests are eventually smothered. As in the prisoner's dilemma, we are driven inexorably to suboptimal outcomes. The logic of the Tragedy of the Commons locks us into a destructive spiral of such vast proportions that we may eventually destroy much of life on this planet.

Solutions to this problem can be placed under two broad headings.

- The Dirigeant Option: Retain the public status of the commons, and allocate permits to exploit the public resources at a level that prevents over-exploitation. Legislate to attach a price to pollution, ranging from light taxes to criminal sanctions.

- The Liberal Option: Privatise the commons, knowing that proprietors are motivated to invest in the development and sustainability of their private property, and generally do not foul their own nests.

Unfortunately, neither of these options satisfactorily solves the problem:

- The dirigeant option presumes that legislative bodies and executive authorities are wise, knowledgeable, incorruptible, attentive and well-intentioned. It also presumes that national authorities have sufficient resources adequately to perform their role as custodians of shared common pool resources. None of these presumptions are true all of the time, often only a few are simultaneously, and in some cases, none are true at all. Whenever you get government attempting to regulate business, you get business attempting to regulate government, corrupting it and undermining democracy. In many countries, the oligarchy of big 
business becomes the government. This is one of the principal structural problems we have today in most of the world. ${ }^{14}$

- The Liberal option merely pushes the Tragedy of the Commons one step down the road; the newly privatised entities exploit and pollute the remaining commons. Since it is not possible to privatise everything, the problems remain unresolved. Furthermore, this solution plays into the hands of the rich and powerful. The majority remain poor while a minority becomes the inheritors of the riches of the earth.

- In extreme cases, such as in some African countries today, a combination of the dirigeant and liberal options jointly fail. This brings about a collapse of capitalism and a regression to the robber baron phase, a stage of economic development that should have passed into history. The growing wealth-gap in most developed economies also betrays the presence of this disease in these countries.

In cases in which the actions of one entity damage the property of another, these damages being externalities with respect to the activity of the parties inflicting the damage, the usual course of action is to sanction the actions with fines or other forms of legislative control. Ronald Coase ${ }^{15}$ argued that where legal rights to open access commons and rights to private property come into conflict, spontaneous local bargaining will occur, leading to internalisation of the costs in the most efficient possible manner. He illustrated this with an example of a cattle rancher negotiating with a crop farmer for access to grazing land. Coase showed that the resolution of disputes that arise when cattle break into farmed land and damage crops will be determined by the relative profitability of cattle-grazing compared to farming. The cattle rancher will agree to pay the farmer for access to grazing land and pay compensation for damages to his crops if the cost is justified by the value of the access and grazing. If, however, the crop is more valuable, then the farmer will demand compensation that the cattle rancher will be unwilling to pay, resulting in a search for other solutions. The cattle rancher might agree to pay for the fence to keep his cattle off the farmer's land if the cost of the fence is less than the compensation that would have to be paid for damaged crops, provided the cost of the fence did not render cattle ranching unprofitable. Coasian bargaining is sensitive to local conditions, is flexible and can adjust to changing circumstances, and incorporates monitoring and sanctions where the participants deem it necessary. Coasian bargaining achieves an economic efficiency that the blunt tool of dirigeant intervention usually cannot.

However, there are three problems with Coasian bargaining. First, the rights of all parties must be established in law before bargaining can take place. Where no statutory rights exist, there are no grounds to force the opposing parties to the bargaining table. We, as people who live in a world increasingly polluted and degraded by the practices of industry, generally have no legal right to seek redress. We suffer in an increasingly polluted world. Second, transaction costs are incurred

\footnotetext{
${ }^{14}$ Barnes, P. (2006) Capitalism 3.0: A Guide to Reclaiming the Commons. Berrett-Koehler.

${ }^{15}$ Coase, R.H. (1960) The Problem of Social Cost. The Journal of Law and Economics. 3, 1-44.
} 
in the process of bargaining. These are especially high when one party comprises many individuals with small marginal interests in the outcome of the bargaining process. It will not be worth their while to be distracted by the business of bargaining when the matters are of no pressing direct concern and the transaction costs exceed their individual expected advantage. These bargains will not be made. Class action suits can help in these cases, but they are in large part not to be relied upon. Third, there are no parties at the bargaining table for the many species whose existence is threatened by our industrial activity, nor are there parties to bargain for such abstractions as 'pristine nature'. Other parties, such as future generations, don't yet exist.

Elinor Ostrom has studied how communities succeed or fail at managing finite open common pool resources such as grazing land, forests, irrigation waters and fisheries. Research shows that local groups closely linked to the resources in question are often capable of sustainable management and efficient extraction of the products of the commons. In many cases, management is more efficiently organised locally than if rules and infrastructure were to be imposed by external authorities to manage the commons. ${ }^{16}$ Ostrom's work shows that the economic model of humans as norm-free myopically short term operators with perfect knowledge of market conditions, focused exclusively on maximizing their individual net worth in monetary terms, is not an adequate model of the complex adaptive systems that comprise real world communities. People are limited in their knowledge, are not wholly rational in their decision-making, are constrained in their choices by cultural factors, are aware of and strongly influenced by social factors such as reputation, and are rarely free of ethical and moral views that may dominate their decision-making. Furthermore, the rulemaking that results in sustainable management of the commons is more like an ongoing dialogue between all entities (individual, corporate and government) evoking an experimental chaotic process that, under the right conditions, will move towards sustainable and efficient management of the commons.

Ostrom's experimental laboratory work showed that players of investment games that incorporated the logic of the prisoner's dilemma, when given the opportunity to discuss strategy in face to face meetings between each iteration, tended to regulate their behavior and win group results that approached the optimum. This held even when the behavior of individual players was not revealed to the other players. ${ }^{17}$ This robust finding shows that public shaming did not play a role in regulating behavior, but rather some internalized sense of group morality constrained individual behavior, leading to positive group results. In other experiments in which players did not enjoy anonymity and were able to devise agreed upon schedules of sanctions against players who broke ranks to obtain unfair shares, up to $95 \%$ of the optimum group yield was achieved by co-operative play.

\footnotetext{
${ }^{16}$ Ostrom, E. (1999) Coping with Tragedies of the Commons. Annual Reviews of Political Science. 2: 493-535.

${ }^{17}$ Ostrom, E., Gardner, R. and Walker, J.M. (1994) Rules, Games and Common-Pool Resources. Ann Arbor: University of Michigan Press.
} 
Ostrom concluded that players used complex heuristics, not game theoretical calculations, to determine their actions. When players are able to meet and agree on strategy, and when given the opportunity to devise their own rules for sanctioning rule breakers in games in which players are not protected by anonymity, they spontaneously regulated their individual behavior so that collective results approached optimum outcomes. ${ }^{18}$ Players tended to react with great indignation against rule breakers, to such a degree that some individuals were willing to impose sanctions on rule breakers at considerable personal cost, occasionally surpassing the loss imposed by the rule breaking, demonstrating that inherent non-rational psychological factors play a role in these behaviors.

Many instances of local community-based initiatives to take control of open common resources and manage them sustainably have been studied and documented. Reviewing these, Ostrom delineated a set of eight conditions that predict success. ${ }^{19}$ In order to ensure sustainable management of the commons, stakeholders should ensure the following:

1. Define clear group boundaries to membership. Increasing the proportion of participants who are well known in a community, and who have a long term stake and reputations of trustworthiness to protect in that community enhances the likelihood that optimal reciprocal behavior will be observed.

2. Match rules governing use of common resources to local needs and conditions. The rules may specify harvesting caps, seasonal restrictions, limitations on the technology used, time of access, and so on. The rules must be seen to be fair.

3. Ensure that those affected by the rules can participate in making and modifying the rules. Research shows that locals are better at specifying rules that actually work. Local groups should be empowered to experiment with rules, which is important for maintaining the effectiveness of the adaptive and continually evolving system. If complex ecological calculations to find carrying capacity are required, for example, it is better to educate the locals than to impose quotas with an authoritarian hand. The latter may lead to rule-breaking and local forces implicitly approving of the rule-breaking.

4. The rule-making rights of community members must be respected by outside authorities. Interference by well-meaning but more distant authorities can break the system. Devolution of authority and explicit support of local decision-making enhances the system.

5. Develop a system carried out by community members for monitoring members' behavior. Informal monitoring among peers will occur spontaneously, but giving it a formal structure will improve the efficiency and adherence to the rules. Permit community members to tinker with the monitoring system to enhance its effectiveness and efficiency.

\footnotetext{
${ }^{18}$ Ostrom, E. (1998) A Behavioral Approach to the Rational Choice Theory of Collective Action. American Political Science Reviews. 92(1): 1-22.

${ }^{19} \mathrm{http}$ ///www.onthecommons.org/magazine/elinor-ostroms-8-principles-managing-commmons 24 May, 2015.
} 
6. Use graduated sanctions for rule violators. Some participants will test the system by breaking the rules and will adjust their behaviour on the basis of the response. Severe sanctions for first offenders can lead to ill-will and can break the system.

7. Provide accessible, low-cost means for dispute resolution. Ensure that higher authorities and avenues of appeal that exist will respect the local decision-making process. Bullying, corruption and political biases can occur at any level. Dispute resolution should be based on clear explicit delineation of rights, by which Coasian bargaining becomes part of the backbone of the system.

8. Build responsibility for governing the common resources in nested tiers from the lowest level up through the entire interconnected system. Keep in mind that the system will be a complex adaptive system that must be able to evolve as conditions change. Evolution of the system should come from the ground up. As far as possible, power should devolve to the lowest possible level, with higher authorities taking educational or mentoring roles in preference to judicial or legislative roles.

We have already noted that human behaviour is not always rational in the way presumed in classical economics. The term 'spite' is used in sociobiology to refer to behaviour that results in greater damage to the spiteful individual than the damage arising from the rule-breaking behaviour of the offending party. How can we explain this behaviour? Similarly, self-sacrificial heroism requires explanation. What does it gain a man to lose his life in battle for the benefit of his fellow warriors? Both spite and heroism can be explained by showing that the loss to the spiteful or heroic individual is more than compensated for by gains among within-group members. Evolution of instincts that drive spiteful and heroic behavior may arise from mechanisms of group selection or of kin selection; not all sociobiologists are in agreement regarding the mechanisms, but all agree that the sum of the gains to within-group individuals in the long term must be greater than the individual losses. This collective non-zero sum drives the evolution of instincts for both spiteful and heroic behaviour. These behaviours are therefore not as irrational as they may appear at first glance. They demonstrate that human behaviour is not solely self-interested in the way classical economists posited.

There appear to be other reasons why behavior is not norm-free myopically short term resource-maximizing strategic play. Most of the highest quality software is open source and free to use. The Internet, for example, runs on a backbone of UNIX that is not proprietary. The open source world is populated by highly talented programmers operating in an informal association, who contribute their time and expertise to the commons with no expectation of direct financial reward. Many of these programmers could earn six digit incomes, which they may forego in order to work on their open source projects. Why? Once again, we must turn to psychological and socio-biological theories to explain this.

The community of open source programmers is held together by their expertise and shared understandings. ${ }^{20}$ You cannot fake your skill in this community; skilled

\footnotetext{
${ }^{20}$ Raymond, E.S. (2001) The Cathedral and the Bazaar: Musings on Linux and Open Source by an Accidental Revolutionary. O'Reilly Media.
} 
programmers can read code as most of us read novels. Excellence is widely understood and appreciated, and uncommon cleverness is greatly admired. Talented members of the open source community can win the approbation of their peers for their contributions. This is what they work for. It has been argued that this is the ultimate reward for which we all strive. Why make money, we may ask, except that we may use it to purchase expensive cars and luxury homes that serve to advertise our success. Such symbols of material success win us the approbation of our peers in the entrepreneurial and corporate world. Money is a means to these ends. A talented programmer can skip the money and go directly to the recognition and status that his skills earn. Money merely gets in the way. The result is a spontaneous self-organizing system that arises from the bottom up and manages the many projects in the collective open source enterprise. The open source world is free of the administrative command structures that characterise the corporate world of commercial software, resulting in a more efficient self-regulating, organically-growing community comprising many of the world's most talented coders. ${ }^{21}$

Sociobiologists argue that the ultimate reward is access to fecund partners and greater reproductive success. It matters not whether this is achieved by acquiring money, fast cars and great estates, or by winning honor and influence in non-monetary ways. If this is so, then the fundamental basis of economic theory is mistaken. Perhaps this explains why a great part, perhaps the greater part, of human endeavor takes place outside the realm of the money economy; the investment that couples make in each other and their offspring is the most obvious example. But is this all there is to being human? Are we just chasing reproductive success, driven by selfish genes that care not what our individual losses may be? ${ }^{22}$

Computer models can be constructed to demonstrate the phenomenon of emergence. ${ }^{23}$ By this we refer to properties of systems that do not appear to be properties of the parts. A widely cited example is found in computer models of ant behavior. These models can be written with a small number of rules for each ant. These rules do not enable any solitary ant to behave in a complex purposeful way. In some models, the solitary ant engages in a random walk until it dies of starvation. However, when many ants are placed together in the virtual space created by the program, seemingly intelligent and purposeful behavior emerges from the interactions between them. Behavioral scientists studying behavior in insects and other species concur that emergent phenomena are necessary to explain complex chaotic self-organizing collective behavior that is observed in nature. Can we extend the concept of emergence to human social behavior? Certainly, although it would be rash to claim that we know what the emergent behaviors are or how to distinguish them from other aspects of human behavior. Nevertheless, it can be argued that the rules encoded into our nervous

\footnotetext{
${ }^{21}$ Steele, R.D. (2012) The Open-Source Everything Manifesto: Transparency, Truth, and Trust. Manifesto Series, Evolver Editions.

${ }^{22}$ Dawkins, R. (1976) The Selfish Gene. Oxford University Press.

${ }^{23}$ Johnson, S. (2002) Emergence: The Connected Lives of Ants, Brains, Cities, and Software. Scribner.
} 
systems bring about new dimensions of emergent behaviors that transcend those predicted by economic and evolutionary laws of nature. Some people argue that the moral dimensions of human behavior are emergent. The spiritual, we are told, is the component that makes the whole something greater than the sum of the parts.

What about the ethical foundations of corporate capitalism?. We all know that the most magnificent and inspirational mission statements hide many sins. The charter of Enron was exemplary, yet this company gave us one of the most egregious examples of rapacious corporate predation and criminality of the last century. ${ }^{24}$ More generally, the advertising industry has fostered a culture of image-creation tantamount to systematic lying, and rendered it ordinary, acceptable, desirable even. Public awareness, itself another aspect of the commons, is corrupted and exploited in the interests of corporate greed. Can international corporations ever possess the emotions of guilt or of pride that may drive moral behavior in individuals? Some argue that a culture of corporate responsibility can arise if senior management sets the standards from the outset. $^{25}$ However, many believe not, and in noting this, we can make a distinction between 'free enterprise' that guarantees rights of individuals and 'corporate capitalism' that has evolved into a global device for exploiting these rights. ${ }^{26}$ The system has become the birthplace of monsters enriching themselves while destroying the planet and undermining a just and equitable society. ${ }^{27}$ It should be cause for alarm to note that none of the mechanisms described by Ostrom operate at the corporate scale. Perhaps it is helpful to quote once again from Adam Smith, the father of economics whose prescient insights were filled with hope and optimism, but also with foreboding and warnings that we seem to have ignored for too long ${ }^{28}$ :

People of the same trade seldom meet together, even for merriment and diversion, but the conversation ends in a conspiracy against the public, or in some contrivance to raise prices.

Open Access This chapter is distributed under the terms of the Creative Commons Attribution-NonCommercial 4.0 International License (http://creativecommons.org/licenses/by-nc/ $4.0 /)$, which permits any noncommercial use, duplication, adaptation, distribution, and reproduction in any medium or format, as long as you give appropriate credit to the original author(s) and the source, a link is provided to the Creative Commons license, and any changes made are indicated. The images or other third party material in this chapter are included in the work's Creative Commons license, unless indicated otherwise in the credit line; if such material is not included in the work's Creative Commons license and the respective action is not permitted by statutory regulation, users will need to obtain permission from the license holder to duplicate, adapt, or reproduce the material.

\footnotetext{
${ }^{24}$ McLean, B., and Elkind, P (2013) The Smartest Guys in the Room: The Amazing Rise and Scandalous Fall of Enron. Portfolio; Reprint Edition.

${ }^{25}$ Collins, J. (2001) Good to Great: Why Some Companies Make the Leap...And Others Don't. Harper Business.

${ }^{26}$ Hamilton S., and Micklethwait, A. (2006) Greed and Corporate Failure: The Lessons from Recent Disasters. Palgrave Macmillan.

${ }^{27}$ Senator Bernie Sanders (March, 1, 2001) The Speech: A Historic Filibuster on Corporate Greed and the Decline of Our Middle Class. Nation Books.

${ }^{28}$ Smith, A. (1776) An Inquiry into the Nature and Causes of the Wealth of Nations. Strahan and Cadell, London.
} 